Original research article

\title{
Development of a patient safety round guideline for nurse managers: Action research study in Indonesia
}

\author{
Setiawan Setiawan *, Dewi Elizadiani Suza, Diah Arruum \\ Universitas Sumatera Utara, Faculty of Nursing, Medan, Indonesia
}

\begin{abstract}
Purpose: The purpose of this study was to develop a patient safety round guideline for nurse managers, in an attempt to strengthen the care culture provided within the hospital.

Methods: This study uses an action research approach, which involved 20 head nurses and the nursing team leaders as participants. In addition, data collection was performed using a qualitative approach, through focus group discussions (FGD) and observations, and quantitative assessment required questionnaires. The data obtained were evaluated using both content analysis and simple statistics.

Results: The study outcome showed that a patient safety round guideline could be used by nurse managers during rounds within the inpatient ward. In addition, the head nurses and nursing team leaders had better knowledge on (1) the implementation of patient safety rounds and (2) the skills applicable in the in-patient ward.

Conclusions: Heads of the nursing division are recommended to create policies that require nurse managers to operate patient safety rounds using a specific guideline at every in-patient ward. This practice ought to be conducted on a regular basis to ensure that all staff activities comply with patient safety.
\end{abstract}

Keywords: Hospital ward; Nurse manager; Patient safety round guideline

\section{Introduction}

Patient safety is a fundamental principle that is conformed to during treatment. Approximately 421 million people are cared for in the in-patient wards worldwide, of which about 42.7 million sustain injuries during the provision of care (World Health Organization, 2017). This form of incidence has befallen 134 million individuals in low-middle income countries, and about 2.6 million deaths have ensued because of unsafe care (National Academies of Sciences, Engineering, and Medicine, 2018). Conversely, 1 in every 10 people are harmed during hospital care that is provided in high-income countries (Slawomirsk et al., 2017).

The burden resulting from medication errors has been estimated at US $\$ 42$ billion per annum, while injury due to unsafe care affects $7.6 \%$ and $10 \%$ of patients suffering from infections in high- and low-income countries, respectively. In addition, about $5 \%$ have diagnostic errors, while approximately $25 \%$ undergo unsafe surgical care, of which 1 million deaths are recorded during or immediately after surgery (World Health Organization, 2019).

It is important for hospitals to maintain patient safety, and avoid loss as well as injury (Bartoníčková et al., 2018). The possibility of reducing these occurrences in hospitals is attain- able by applying a patient safety round (Wagner et al., 2014). Therefore, effective implementation is capable of reducing the Hospital Associated Infection (HAIs) rate, including Ventilator-Associated Pneumonia (VAP) by an average of 0.19 to 0.09 , peripheral bloodstream infection by 2.8 to 1.6 per 1000 , infection around the operating area by 3.8 to 2.6 per 1000 , catheter-associated urinary tract infection by 1.4 to 2.7 per 1000 in a year (Phipps et al., 2018). The patient safety round is a program which promotes freedom from preventable harm/injuries, or those with the potential to occur in association with the health service (Hashjin et al., 2014).

The implementation of this strategy has proven to be an effective tool in the development of safety culture and also serves as a reference for improving the organization at all levels. This approach allows team members (encompassing the senior management) to engage in a structured conversation (Tucker and Singer, 2015). The improved patient safety round involves the presence of a senior executive committed to receiving staff comments and motivating employees. This is needed to increase participation and provision of more quality services, and also to collaboratively identify related challenges faced by front-line staff (Saadati et al., 2019).

In Indonesia, an increase in the incidence of injuries to patients during hospitalization, alongside the absence of standard guidelines to ensure a patient safety round, has led to the

\footnotetext{
* Author for correspondence: Setiawan Setiawan, Universitas Sumatera Utara, Faculty of Nursing, Jl. Prof. Maas No. 3, Kampus USU Medan, 20155, Indonesia; e-mail: setiawan@usu.ac.id http://doi.org/10.32725/kont.2020.025
}

Submitted: 2020-02-18 • Accepted: 2020-07-15 • Prepublished online: 2020-07-28 
suboptimal implementation of care measures. This development is important to ensure a reduction in the incidence of harm and injuries in hospitals. Therefore, the aim of this study was to provide an in-depth description of patient safety round guideline development for nurse managers in Indonesian hospitals.

\section{Materials and methods}

\section{Study design}

A qualitative method with an action research approach was used in accordance with Kemmis et al. (2014). This consisted of 4 stages, including reconnaissance, planning, acting and observation, and reflection.

\section{Sample/participants}

The participants included 20 head nurses and team leaders in Medan teaching hospital. They were selected using purposive sampling, based on the following inclusion criteria: (1) able to communicate, (2) mentally and physically healthy, (3) willing to be a participant.

\section{Data collection}

The study was conducted from May to October 2019, and the data collection methods used were focus group discussion (FGD), self-report, observation, and field notes. The tools used included (1) voice recorder, (2) FGD guideline, (3) a questionnaire about the nurse manager's knowledge on patient safety rounds (4) a questionnaire about the nurse manager's skill in implementing the guideline.

In this study, the data collection stage was carried out in 4 phases:

\section{Phase 1: Reconnaissance}

Reconnaissance is a preliminary study, where the nurse manager's knowledge of the nursing round and the skills applied to attain patient safety are measured.

\section{Phase 2: Planning}

Research planning and results of measurement data at the reconnaissance stage are disseminated. This is followed by preparations for actions to be taken during the implementation of the rounds, which is then submitted for the development of a guideline. Thus, the tentative guideline is developed in this phase.

\section{Phase 3: Act and observe}

The preparation and implementation of a tentative guideline are carried out in this phase. This is followed by observations to determine the nurse manager's skills in conducting the round. In addition, field notes are then used to describe the current situation of the research - this is at the stage of action and observation.

\section{Phase 4: Reflection}

The nurse manager's knowledge of the round and the inherent skills to apply the tentative guideline are measured again. During this phase, the researchers and participants encounter the following: (1) identify supporting and inhibiting factors for the implementation of patient safety guidelines, (2) evaluate actions (3) provide solutions to problems during the execution. Therefore, the focus was on analyzing the problem, assessing the participants' ability, and summarizing the results of reflection in order to produce a guideline series to reduce the number of injuries during a stay in hospital.

\section{Data analysis}

Data analysis used qualitative and quantitative approaches, which were evaluated by content analysis and descriptive statistics. Colaizzi (1978) reported ten stages of content analysis: (1) compile and read all transcripts, (2) identify and (3) write significant statements into prepared tables to facilitate categorization, (4) ascertain the statements to ensure that none are missed, (5) sort in an ascending mode, (6) provide codes for each, (7) group similar codes into categories, (8) re-identify the suitability of placement in each category, (9) group similar categories (10) determine themes and sub-themes. During qualitative data analysis, field notes serve as supporting or additional information needed to strengthen the assessment prior to the determination of themes. Conversely, the quantitative data obtained from observational knowledge and skills were analyzed using descriptive statistical tests. This was done to identify the differences in the average knowledge value of nurses pertaining to a tentative guideline, and also the skills applicable to guarantee a patient safety round by nurse managers - before and after implementation.

\section{Trustworthiness/rigor}

The principle of trustworthiness was applied to ensure accuracy in qualitative research. This comprised credibility, transferability, dependability, and confirmability (Lincoln and Guba, 1985). Specifically, credibility was maintained through prolonged engagement techniques, observation, comprehensive field notes, triangulation, and member checking, which was performed with reference to the truth of data and its interpretation. The concept of transferability depends on the researcher's knowledge of the sender's and the recipient's context - attained through detailed descriptions. Meanwhile, dependability was conducted by checking the FGD and field notes (as well as observations) in order to produce themes for participants and to maintain data stability. Furthermore, confirmability was carried out by result examination, which involved the input of three nurse experts in the aspect of patient safety.

\section{Ethical considerations}

This study was approved by the Health Research Ethics Commission of the Nursing Faculty, Universitas Sumatera Utara No. 876 /V/SP/2019. Informed consent was obtained for this study.

\section{Results}

This study recruited 20 participants, consisting of head nurses and team leaders. Most of them were aged 36-45 years. Meanwhile, most of the participants held bachelor's degrees in nursing (90\%), while the other participants held master's degrees (Table 1).

This study was comprised of 4 phases, including reconnaissance, planning, acting and observing, and reflecting.

\section{Reconnaissance}

Activities carried out at this stage include (1) study location identification, and conducting prolonged involvement, (2) participant knowledge assessment, (3) observation of patient safety round implementation by nurse managers, (4) observation of the correct completion of documentation forms in the wards. Activities during reconnaissance (in order to be familiar with the study location) and the prolonged engagement were carried out for 2 months (from May to June 2019). The 
Table 1. Demographic characteristics of the participants $(n=20)$

\begin{tabular}{lrc}
\hline Characteristic & $n$ & $\%$ \\
\hline Age & & \\
26-35 years & 9 & 45 \\
36-45 years & 11 & 55 \\
Education & & \\
$\quad$ Master's & 2 & 10 \\
$\quad$ Bachelor's & 18 & 90 \\
Position & & \\
$\quad$ Head nurse & 9 & 45 \\
Team leader & 11 & 55 \\
\hline
\end{tabular}

thematic agreement in this study showed the absence of guidance in relation to safety round implementation - based on the results of focus group discussions and the measurement of nurse manager knowledge levels. Therefore, it is necessary for nurse managers to develop guidelines to facilitate the creation of a patient safety culture atmosphere in the field of nursing at hospitals.

Table 2 shows that the nurse manager's knowledge of patient safety rounds before the process was performed was good. This was due to the conformity between about 13 people $(65 \%)$ and insufficient categories of 7 people (35\%).

Table 2. Nurse manager's knowledge level before performing patient safety round

\begin{tabular}{|c|c|c|}
\hline Knowledge & $\begin{array}{l}\text { Absolute frequency } \\
\text { (n) }\end{array}$ & $\begin{array}{l}\text { Relative frequency } \\
\text { (\%) }\end{array}$ \\
\hline Good & 13 & 65 \\
\hline Enough & 7 & 35 \\
\hline Less & 0 & 0 \\
\hline Mean & & \\
\hline
\end{tabular}

\section{Planning}

During the planning stage, researchers deliberated over the preparation of a tentative patient safety round guideline. This preparation also involved all of the ward heads and several team leaders (through the FGD). This was followed by setting a two-month patient safety round implementation schedule, and planning an evaluation timeline. Subsequently, a strategy requesting the participation of three external nurses with expertise on patient safety to review the guideline was drafted.

\section{Acting and observing}

The first activity in this phase was the performance of a FGD to prepare the draft or tentative patient safety round guideline. This was conducted on August 8, 2019. The activity involved 20 people, encompassing all nurse managers and several team leaders, and the tentative guideline created was consequently implemented.

The safety round implemented by nurse managers was initiated between August 13, 2019, and September 12, 2019. This process was performed twice a week in a total of 8 inpatient wards, emergency rooms, surgery center rooms, and hemodialysis rooms.

The results of observing this first implementation phase showed that a number of nurse managers evaded the introductory briefing process. Another finding was that during their performance of rounds, some nurse managers only conducted an interview with one staff nurse - which does not comply with the guideline that states a nurse manager should interview 2 staff nurses when conducting a patient safety round. In addition, one of the managers performed a patient safety round for over 45 minutes, hence the conclusive briefing process was not performed.

This phase is characterized by the correct optimal implementation of the patient safety round by the nurse manager.

\section{Reflecting}

This phase involved performing an FGD on September 13, 2019 , in order to obtain input on the implementation performed in 8 inpatient wards, emergency rooms, surgery center rooms, and hemodialysis rooms for 2 months. The results showed the new experience encountered by nurse managers which was previously non-existent. Also, it is necessary to periodically conduct patient safety rounds in hospitals in order for nurses to maintain the safety culture. The managers saw the benefits as team leaders and nurses tend to be more aware of the importance of maintenance, and consequently make an effort to augment safety practices within the inpatient ward. This outcome is due to the increased knowledge, and changes in the mindset of nurses who become more aware of the need for implementation continuity.

\section{Output of action research}

The output of this action research study is the creation of a patient safety round guideline, expected to be used by nurse managers in executing best practices at inpatient wards. This guideline consists of 5 toolkits, including the patient safety round implementation guideline (tool 1 ), interview guide (tool 2) and observation guide (tool 3), as well as safety indicators (tool 4), and round report (tool 5). The patient safety round implementation guideline consists of 12 steps in implementing the round that must be carried out by nurse managers over a duration of approximately 45 minutes. The interview guide consists of 7 open-ended questions that are asked during the implementation. The observation guide comprises of 12 statement items related to the adequacy of equipment and environment. Safety indicators refer to 6 items of International Patient Safety Goals determined by Joint Commission International (JCI). A round report is a short way of summarising important findings related to patient safety concerns (and other related findings) during an interview with nurses and patients.

A number of changes were implemented into nurses' daily practice after the action research project in this hospital such as (1) the patient safety round is performed by a nurse manager every 2 weeks in 8 inpatient wards, emergency rooms, surgery center rooms, and hemodialysis rooms, (2) patient education about patient safety is well documented, (3) patient identification is completed every time a meeting with the patient occurs and before any action or procedure is taken, (4) double checks are always performed by nurses before administering high alert medications, and (5) triangle signs that indicate a risk of falling in patients with a high fall risk are always placed at the patient's bed.

\section{Outcomes of action research}

A total of 2 results were obtained from this study. First, there was an increase in the knowledge of the nurse managers concerning the implementation of a patient safety round, while the second demonstrates an elevation in the skills required.

Table 3 shows an increase in the mean score of the nurse manager's knowledge about the patient safety round after implementation (with a mean of 17.55). 
Table 3. Nurse manager's knowledge level after performing patient safety round

\begin{tabular}{lcc}
$\begin{array}{l}\text { Knowledge } \\
\text { Good }\end{array}$ & $\begin{array}{c}\text { Absolute frequency } \\
(n)\end{array}$ & $\begin{array}{c}\text { Relative frequency } \\
(\%)\end{array}$ \\
Enough & 20 & 100 \\
Less & 0 & 0 \\
Mean & 0 & \\
\hline
\end{tabular}

Table 4 shows an increase in nurse manager skills by $12 \%$ after the implementation of the process.

Table 4. Nurse manager's skill in patient safety rounds

\begin{tabular}{lrrrr} 
Knowledge & \multicolumn{2}{c}{ Stage I } & \multicolumn{2}{c}{ Stage II } \\
\cline { 2 - 6 } & $n$ & $\%$ & $n$ & $\%$ \\
\hline Optimal & 1 & 5 & 20 & 100 \\
Sub-optimal & 19 & 95 & 0 & 0 \\
Mean & \multicolumn{2}{c}{10.05} & \multicolumn{2}{c}{12} \\
\hline
\end{tabular}

\section{Discussion}

\section{Reconnaissance}

To develop this patient safety round guideline, a study design through an action research approach was used. Hale and McNab (2015) conducted a similar investigation on the development of a patient safety round checklist in the United Kingdom. The implementation led to an increase from $45 \%$ to $89 \%$, with an average of $70 \%$ during the nine months of the checklist modification - based on the feedback of the staff involved.

In addition, problem identification is determined by the existence of trustworthiness between researchers and participants at the study site. Prolonged engagement for 2 months is expected to build trust and openness in order to obtain genuine data (Korstjens and Moser, 2018). Meanwhile, information sourced for action research was collected through a focus group. According to Hegney and Francis (2015), FGD is often adopted to identify information from issues in a research setting, and the results are expected to provide positive or negative input. Furthermore, data triangulation was conducted to ascertain the validity and suitability of information obtained from different sources (Fusch et al., 2018).

The nurse manager's knowledge of the patient safety round prior to the implementation was at $65 \%$, which is a positive indicator in the hospital. This is consistent with the outcome of previous studies (Amiri et al., 2018), stipulating the higher tendency for an individual with continuous exposure to similar information to possess good knowledge; and consequently elevating the skills possessed.

\section{Planning}

This stage features the preparatory activities for planned socialization, which include the specification of time and place, socialization of participants, and the material delivered during the process. Therefore, a tentative arrangement was conducted with the aim of determining the time to prepare the guideline - which involves the head nurses and team leaders. Also, it is important to maintain coordination, characterized by the establishment of communication channels between people performing different jobs. This was intended to improve the actions of the implementers that are nonadherent to the selected plan (Vanagas and Stankevič, 2015).

\section{Acting and observing}

This phase involves the guideline execution, which requires the preparation of head nurses and team leaders. It is based on the results of FGD, and the questionnaire on the nurse manager's knowledge and inherent skills pertaining to patient safety rounds obtained at the reconnaissance stage - as well as a literature review for the improved implementation. Gibbs et al. (2017) reported the importance of including a literature review as a source during the critical analysis of the relationship between different studies. This is also relevant in linking researches with current investigations aimed at preparing theories.

The patient safety round guideline development process uses an action research study approach. Sølvtofte et al. (2017) discussed the effective implementation by senior leaders which ultimately improved patient safety culture. Furthermore, an increase in the performance frequency led to the provision of better care quality (Johnston et al., 2019), as patients feel more protected from harm and injury. Similarly, a study conducted by Al-Mandhari et al. (2018) on the development of patient safety initiative (based on tools from WHO) which was applied for one year in selected hospitals, found that these hospitals had successful outcomes in improving patient safety.

The implementation of safety procedures created positive changes in head nurses, team leaders, and staff. Furthermore, there was better awareness about maintenance and enhancement approaches within the ward, alongside elevated knowledge and changes in the mindset of nurses - characterized by greater awareness of the need for continuous implementation.

This study was congruent with the report by Tucker and Singer (2015), where a patient safety round was proven to be an effective tool in the development of safety culture. This also contributed to the identification of adverse impact risks, and as a reference strategy for improving organizations at all levels.

These improvement skills were inseparable from the leadership role in an organization (Bartoníčková et al., 2018). As this study involved nurse managers and nursing team leaders, it is clear that they have vital leadership roles in improving patient safety culture through conducting patient safety rounds at all hospital wards. The study conducted by Danielsson et al. (2015) showed the positive impact of an individual's management ability on patient safety. Therefore, nurse managers are expected to act as role models for others, by setting a good example to be followed.

\section{Reflecting}

Reflecting is the last step in the cycle of an action research study, where the output in the form of a patient safety round guideline is evaluated. This process was similar to Simbolon et al. (2015), which was applied in developing care code guidelines for nurses' education, although only 1 tool (caring code) was analyzed for the undergraduate students. However, this current investigation consisted of 5 tools, including a patient safety round implementation guide (tool 1 ), interview guide (tool 2), and observation guide (tool 3), as well as patient safety indicators (tool 4) and round report (tool 5).

At this stage, researchers evaluated the nurses' knowledge and implementation skills pertaining to a patient safety round guideline. Kemmis et al. (2014) linked the reflection with the evaluation stage and the obstacles manifested in the action strategy, taking into account various possible situations. 
In addition, an increase in knowledge about the patient safety round and implementation skills was observed before and after the procedure, with the following mean: (1) the knowledge before and after were 14.90 and 17.55 respectively, while (2) the nurse manager skills stage I and II were 10.05 and 12 correspondingly. These findings were congruent with the research of Morath et al. (2014), which revealed a positive impact of performance on the nurse managers, as well as the staff nurses. This phenomenon was due to the occurrence of more open discussions related to the enhancement of safety culture, although the most significant dimension was obtained with teamwork in a unit (Danielsson et al., 2017).

Following the implementation of patient safety rounds, it was important to pay attention to the communication pattern employed by the nurse managers. This is a vital aspect because the ability largely determines the information obtained by the information recipient. Furthermore, it is possible for communication inconveniences between staff nurses and managers to prevent the completion of rounds, due to the intrinsic role in realizing positive work goals (Sibiya, 2018). However, each organization is expected to have leaders with the capacity to direct open communication from staff about patient safety issues (Bednarova et al., 2019); Sølvtofte et al., 2017). This parameter was considered one of the most significant obstacles in the integration of theory, practice, and research. Therefore, the theory of action study approach is better understood and applied in practice, following the delivery of good communication, which is acceptable by all participants (Moch et al., 2016).

There were two limitations in this study. First, implementation of the developed patient safety round guideline only involved a few nurses (including all nurse managers and nursing team leaders as the participants), and second, a short period of the guideline implementation. In addition, every ward only had 4 visits by nurse managers during the execution.
Despite these limitations, it is possible to apply the outputs of this study in hospitals for creating policies related to patient safety rounds. This is needed to facilitate the care culture, especially in Indonesian hospitals.

\section{Conclusions}

This was an action research study that produced an output in the form of a patient safety round guideline for nurse managers. Proper implementation is vital in the provision of awareness on the importance of patient safety required to prevent harm or injury during hospitalization. The hospitals are, therefore, expected to enable all nursing staff to participate in related trainings.

\section{Acknowledgements}

The authors are grateful to Universitas Sumatera Utara Rector and Head of Institutional Research. This research was funded by Universitas Sumatera Utara Talenta Grant. Grant number: 4167/UN5.1.R/PPM/2019.

\section{Contributions of the authors}

Setiawan created and conducted the research, then further analyzed and interpreted the data - which was then drafted and critically revised. Dewi Elizadiani Suza provide analysis and interpretation. Diah Arruum conducted data collection and analysis.

\section{Conflict of interests}

The authors have no conflict of interests to disclose.

\section{Vývoj směrnic pro bezpečnost pacientů během obchůzek vedoucích sester: akční výzkum v Indonésii}

\section{Souhrn}

Cíl: Účelem této studie bylo vyvinout směrnice pro bezpečnost pacientů během obchůzek vedoucích sester ve snaze posílit kulturu péče poskytované $\mathrm{v}$ nemocnici.

Metody: Tato studie využívá metodu akčního výzkumu, kterého se zúčastnilo 20 vedoucích sester a vedoucích ošetřovatelských týmů. Kromě toho byl sběr dat proveden pomocí kvalitativního přístupu, prostřednictvím skupinových diskusí (Focus Group Discussions) a pozorování, a kvantitativním hodnocením požadovaných dotazníků. Získaná data byla vyhodnocena pomocí obsahové analýzy a jednoduché statistiky.

Výsledky: Výsledek studie ukázal, že směrnice pro bezpečnost pacientů mohly během obchůzek na nemocničních lůžkových odděleních používat vedoucí zdravotní sestry. Kromě toho měly vedoucí sestry a vedoucí ošetřovatelských týmů lepší znalosti o (1) implementaci bezpečnostních obchůzek a (2) dovednostech použitelných na lůžkových odděleních.

Závěr: Vedoucím ošetřovatelské divize se doporučuje, aby vytvořili zásady, které vyžadují, aby vedoucí sestry provozovaly bezpečnostní obchůzky pomocí specifických směrnic pro každé lůžkové oddělení. Tato praxe by měla být prováděna pravidelně, aby se zajistilo, že všechny činnosti personálu jsou v souladu s bezpečností pacientů.

Klíčová slova: hlavní sestra; nemocniční oddělení; směrnice pro bezpečnost pacientů během obchůzek

\section{References}

1. Al-Mandhari A, Al-Farsi S, Al-Barwani S, Al-Salmani N, AlRabhi S, Al-Saidi, S, et al. (2018). Developing patient safety system using WHO tool in hospitals in Oman. Int J Qual Health Care 30(6): 423-428. DOI: 10.1093/intqhc/mzy050.

2. Amiri M, Khademian Z, Nikandish R (2018). The effect of nurse empowerment educational program on patient safety culture:
A randomized controlled trial. BMC Med Educ 18(1): 1-8. DOI: 10.1186/s12909-018-1255-6.

3. Bartoníčková D, Kalánková D, Mikšová Z, Žiaková K, Mazalová L (2018). Patient safety culture from a nursing point of view in a broader context. Kontakt 21(2): 121-127. DOI: $10.32725 /$ kont.2018.008.

4. Bednarova M, Hirsova M, Komarkova L (2019). Leadership Style and Its Influence on Employee Identification with the Organization: A Study from a Czech Hospital. Kontakt 21(3): 279-284. DOI: 10.32725/kont.2019.035 
5. Colaizzi PF (1978). Psychological research as a phenomenologist views it. In: Valle RS, King M (1978). ExistentialPhenomenological Alternatives for Psychology. New York: Open University Press.

6. Danielsson M, Carlfjord S, Nilsen P (2015). Patient safety walk rounds: views of frontline staff members and managers in Sweden. Int J Nurs 2(2): 81-93. DOI: 10.15640/ijn.v2n2a10.

7. Danielsson M, Nilsen P, Rutberg H, Årestedt K (2017). A National Study of Patient Safety Culture in Hospitals in Sweden. J Pat Saf 15(4): 328-333. DOI: 10.1097/ PTS.0000000000000369.

8. Fusch P, Fusch GE, Ness LR (2018). Denzin's paradigm shift: Revisiting triangulation. JSC 10(1): 19-32. DOI: 10.5590/ josc.2018.10.1.02.

9. Gibbs P, Cartney P, Wilkinson K, Parkinson J, Cunningham S, James-Reynolds C, et al. (2017). Literature review on the use of action research in higher education. Educ. Action Res 25(1): 3-22. DOI: 10.1080/09650792.2015.1124046.

10. Hale G, McNab D (2015). Developing a ward round checklist to improve patient safety. BMJ Qual Improv Rep. 4(1): u204775. w2440. DOI: 10.1136/bmjquality.u204775.w2440.

11. Hashjin AA, Kringos DS, Manoochehri J, Ravaghi H, Klazinga NS (2014). Implementation of patient safety and patient-centeredness strategies in Iranian hospitals. PLoS ONE 9(9): e108831. DOI: 10.1371/journal.pone.0108831.

12. Hegney DG, Francis K (2015). Action research: changing nursing practice. Nursing Standard (Royal College of Nursing (Great Britain) : 1987) 29(40): 36-41. DOI: 10.7748/ ns.29.40.36.e8710.

13. Johnston BE, Lou-Meda R, Mendez S, Frush K, Milne J, Fitzgerald T, et al. (2019). Teaching patient safety in global health: Lessons from the Duke Global Health Patient Safety Fellowship. BMJ Glob Health 4(1): e001220. DOI: 10.1136/ bmjgh-2018-001220.

14. Kemmis S, McTaggart R, Nixon R (2014). The Action Research Planner: Doing Critical Participatory Action Research. Singapore: Springer. DOI: 10.1007/978-981-4560-67-2.

15. Korstjens I, Moser A (2018). Series: Practical guidance to qualitative research. Part 4: Trustworthiness and publishing. Eur J Gen Pract 24(1): 120-124. DOI: $10.1080 / 13814788.2017 .1375092$.

16. Lincoln YS, Guba EG (1985). Naturalistic Inquiry. Thousand Oaks: Sage Publications.

17. Moch SD, Vandenbark RT, Pehler SR, Stombaugh A (2016). Use of Action Research in Nursing Education. Nurs Res Pract 2016: 8749167 DOI: $10.1155 / 2016 / 8749167$.

18. Morath J, Filipp R, Cull M (2014). Strategies for enhancing perioperative safety: promoting joy and meaning in the workforce. AORN Journal 100(4): 376-389. DOI: 10.1016/j. aorn.2014.01.027.
19. National Academies of Sciences, Engineering, and Medicine (2018). Crossing the global quality chasm: Improving health care worldwide. Washington, DC: The National Academies Press. DOI: $10.17226 / 25152$.

20. Phipps AR, Paradis M, Peterson KA, Jensen J, Nielsen K, Hall M, et al. (2018). Reducing Serious Safety Events and Priority Hospital-Acquired Conditions in a Pediatric Hospital with the Implementation of a Patient Safety Program. Jt Comm J Qual Patient Saf 44(6): 334-340. DOI: 10.1016/j.jcjq.2017.12.006.

21. Saadati M, Nouri M, Rezapour R (2019). Patient safety walkrounds; 5 years of experience in a developing country. Int J Health Plann Manag 34(2): 773-779. DOI: 10.1002/ hpm.2734.

22. Sibiya MN (2018). Effective Communication in Nursing. In: Ulutasdemir N (2018). Nursing. London: IntechOpen. DOI: 10.5772/intechopen.74995.

23. Simbolon SM, Setiawan S, Fathi A (2015). Pengembangan Caring Code Dalam Pendidikan Ners Tahap Akademik Di STikes Santa Elisabeth Medan [Development of caring code in undergraduate nursing program at Santa Elisabeth School of Nursing, Medan]. Idea Nursing Journal 6(2): 21-29.

24. Slawomirsk L, Auraaen A, Klazinga N (2017). The Economics of patient safety. OECD [online] [cit. 2020-05-31]. Available at: https://www.oecd.org/els/health-systems/The-economics-ofpatient-safety-March-2017.pdf

25. Sølvtofte AS, Larsen P, Laustsen S (2017). Effectiveness of Patient Safety Leadership Walk RoundsTM on Patient Safety Culture: A Systematic Review Protocol. JBI Database System Rev Implement Rep 15(5): 1306-1315. DOI: 10.11124/ JBISRIR-2016-003004

26. Tucker AL, Singer SJ (2015). The Effectiveness of ManagementBy-Walking-Around: A Randomized Field Study. Prod Oper Manag 24(2): 253-271. DOI: 10.1111/poms.12226.

27. Vanagas R, Stankevič J (2015). Impact of coordination for organization process. Intellectual Economics 8(2): 112-125. DOI: 10.13165/ie-14-8-2-08.

28. Wagner C, Thompson CA, Arah OA, Groene O, Klazinga NS, Dersarkissian M, et al. (2014). A checklist for patient safety rounds at the care pathway level. Int J Qual Health Care, 26(Suppl. 1): 36-46. DOI: 10.1093/intqhc/mzu019.

29. World Health Organization (2017). Patient Safety Making health care safer. [online] [cit. 2020-05-31]. Available at: https://apps.who.int/iris/bitstream/handle/10665/255507/ WHO-HIS-SDS-2017.11-eng.pdf? sequence=1\&isAllowed=y

30. World Health Organization (2019). Patient Safety; Global action on patient safety. [online] [cit. 2020-05-31]. Available at: https://apps.who.int/gb/ebwha/pdf_files/EB144/ B144_41Rev1-en.pdf 